\title{
Meta
}

Journal des traducteurs

Translators' Journal

\section{First Imitate, then Translate: Histories of the Introduction of Stream-of-Consciousness Fiction to China}

\section{Leo Tak-Hung Chan}

Volume 49, numéro 3, septembre 2004

L'histoire de la traduction et la traduction de l'histoire History of Translation and Translation of History

URI : https://id.erudit.org/iderudit/009386ar

DOI : https://doi.org/10.7202/009386ar

Aller au sommaire du numéro

Éditeur(s)

Les Presses de l'Université de Montréal

ISSN

0026-0452 (imprimé)

1492-1421 (numérique)

Découvrir la revue

Citer cet article

Chan, L. T. (2004). First Imitate, then Translate: Histories of the Introduction of Stream-of-Consciousness Fiction to China. Meta, 49(3), 681-691.

https://doi.org/10.7202/009386ar
Résumé de l'article

En Chine, le stream-of-consciousness (monologue intérieur) a été considéré comme intraduisible pendant une période de temps. Toutefois, $a \mathrm{xx}^{\mathrm{e}}$ siècle, on assiste à un foisonnement d'imitations de ce genre littéraire. Plusieurs écrivains chinois employaient cette technique dans leurs romans, d'abord dans les années 1930, ensuite dans les années 1960 et finalement dans les années 1980. La traduction de romans " difficiles " tels ceux de James Joyce et Virginia Woolf apparaîtront seulement dans les années 1990. Comment peut-on comprendre le phénomène des traductions suivant les imitations dans l'histoire du stream-of-consciousness en Chine? 


\title{
First Imitate, then Translate: Histories of the Introduction of Stream-of-Consciousness Fiction to China'
}

\author{
LEO TAK-HUNG CHAN \\ Lingnan University, Tuen Mun, Hong Kong \\ chanleo@ln.edu.hk
}

\begin{abstract}
RÉSUMÉ
En Chine, le stream-of-consciousness (monologue intérieur) a été considéré comme intraduisible pendant une période de temps. Toutefois, au $x^{e}$ siècle, on assiste à un foisonnement d'imitations de ce genre littéraire. Plusieurs écrivains chinois employaient cette technique dans leurs romans, d'abord dans les années 1930, ensuite dans les années 1960 et finalement dans les années 1980. La traduction de romans «difficiles» tels ceux de James Joyce et Virginia Woolf apparaîtront seulement dans les années 1990. Comment peut-on comprendre le phénomène des traductions suivant les imitations dans l'histoire du stream-of-consciousness en Chine?
\end{abstract}

\begin{abstract}
In China, stream-of-consciousness (SOC) fiction had for some time been thought of as untranslatable. By contrast, SOC imitations appeared in abundance through the twentieth century, attempted by several Chinese writers who consciously used the technique in their own novels, first in the thirties, then in the sixties, and finally in the eighties. It was not until the nineties, however, that the "difficult" novels by James Joyce and Virginia Woolf, among others, were translated. How can we understand the phenomenon of translations following imitations in the history of SOC fiction as introduced to China?
\end{abstract}

\section{MOTS-CLÉS/KEYWORDS}

imitations, stream-of-consciousness fiction, history of translation, transplantation, modernism

The introduction of stream-of-consciousness writing to China in the twentieth century has had a curious history. In particular, it engages our attention because both translations and imitations were undertaken with great fervor, during a period of over seventy years. In surveying the histories that have been written on the subject, one is repeatedly confronted with issues of seminal interest in literary and translation studies. Translations and imitations are often viewed as separate phenomena, giving rise to two separate, rival histories. Yet what seems beyond doubt, too, is their interrelatedness, as well as their resemblance to indigenous writing not inspired by Western examples. ${ }^{2}$ Bearing in mind Northrop Frye's famous adage that "great writers plagiarize, bad ones imitate," how can we relate imitation to translation in the Chinese context?

Much translation research has focused on prototypical translations, feeling uneasy about how imitations, tangentially linked to their originals, can be positioned against the more text-bound kinds of translation. Functionally, however, they are similar in that both make possible the transposition of foreign literary models and 
conventions. The same can be said of adaptations, of course, but in comparison with adaptations, imitations have had a more fluid identity. While adaptations are widely recognized as a variant form of translation and usually given a place within a history of translations, imitations are not. The histories of the introduction of stream-ofconsciousness novels in China reflect the difficulty of integrating imitations into a general history of translation.

Brief reference needs to be made to the tripartite division of translation types according to John Dryden, which reflected traditional Western thinking on the nature and scope of translation since ancient times. ${ }^{3}$ Dryden shows little sympathy for imitations, his third category of texts, and expresses a clear preference for translations ("paraphrases") that are faithful to the sense of the original. Paradoxical as it may seem, however, he considers imitations as a viable category of translation. It is the degree of freedom, or departure from the original, that differentiates for him a translation from an imitation. To Dryden's conceptualization one can add this: imitations can be distinguished from translations on the basis of their departure from indigenous modes of literary expression. Foreign literature and home literature, then, become the two poles in the direction of either of which translations and imitations slant (see Figure 1). Many histories have been written of the transplantation of stream-of-consciousness fiction to China, but there is always an either/or mentality with regard to translation vs. imitation. This has resulted in some one-sided accounts of what was a multi-faceted tale.

FIGURE 1

Relationship between Translation and Imitation

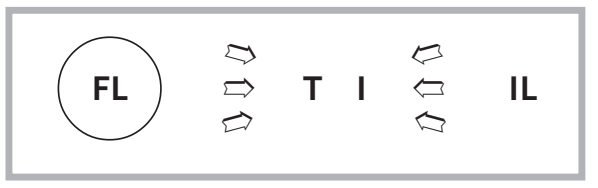

$\mathrm{FL}=$ foreign literature

$\mathrm{T}=$ translation

$\mathrm{I}=$ imitation

$\mathrm{IL}=$ indigenous literature

\section{Literary and Linguistic Parameters}

There is serious obfuscation in definition of "stream of consciousness." While comparable methods of presenting characters' thought have been in use since the seventeenth century, ${ }^{4}$ the novelistic genre in which thought at both conscious and subconscious levels figures prominently emerged only at the end of the nineteenth century. This genre signals what critics have called an "inward turn of narrative," characterizing the shift of narrative emphasis from external actions to the activities of the mind, portrayed differently from author to author. As well, while some critics prefer to think of "stream of consciousness" as the all-embracing, over-arching term for the various techniques used, others prefer more restricted definitions - William Tay, for one, insists that free associations be considered a defining feature. As for the classification of stream-of-consciousness techniques, the major categories are: inte- 
rior monolgue, embedded dialogue, free indirect discourse, and objective descriptions which convey sensory perceptions. Thus Dorrit Cohn's threefold classification (psycho-narration, quoted monologue and narrated monologue) contrasts with Taraja Rouhiainen's binary division of methods into (a) free direct discourse and (b) free indirect discourse. ${ }^{5}$

As far as the introduction of stream-of-consciousness fiction to China via translations and imitations is concerned, the implications are both literary and linguistic. In the first place, from the reception end, in general a resistance to (or denial of) new literary forms is evident - a resistance more obvious in imitations than translations. Whatever the actual impact exerted by all the imitations since the thirties, many critics have commented that methods of thought presentation similar to those of the West have already been in existence in traditional China, as if to sally the impact. ${ }^{6}$ The introduction of foreign modes, accordingly, conjures up hidden ghosts of the past. Scholars simply culled the classical Chinese novels for evidence to prove their point.

Secondly, since the stream of consciousness entails radical linguistic experimentation, the issue of language change caused by translations and imitations in this genre becomes prominent. On the whole, translations seem to have played a more crucial role than imitations, by virtue of their closeness to the original foreign texts. Again one witnesses a duplicity in critical attitudes: linguistic influences, while beneficial, are believed to be local at best. ${ }^{7}$ Often emphasized in the histories in question are the linguistic features of Chinese as a receptor language that mould the way in which foreign literary models are received. Though the key stylistic elements of the stream-of-consciousness technique (elimination of punctuation, repetition of key words to link long sentences together, fronting of those ideas that carry prominence in a character's mind, extensive use of colloquialisms, broken sentences and so on) are conspicuous in the original texts, they are believed to have been carried across more forcefully in translations than in imitations. ${ }^{8}$ That is perhaps another reason why translations are more resisted than imitations.

The several histories presented below, almost unwittingly, share a simplifying tendency, selecting for discussion only particular agents (authors and translators), valorizing a handful of works (original texts or translations or imitations), and focusing on either one of the two Chinese-speaking regions (the Mainland and Taiwan/ Hong Kong). They are thus exclusionary accounts, each in its own way aspiring to be authoritative. The explanatory schemes offered also vary: different reasons are cited as to why the genre was permitted entry into China. They even evince a wide array of concerns: some focus on what was translated or imitated, others on the pioneers of the foreign genre, and still others on reception issues. Essentially, however, there were the two opposed camps of literary and translation historians.

\section{0s: Reform Era Imitations}

One central concern of the various histories is: "What was the first Chinese specimen of stream of consciousness?"9 As early as the late seventies, widespread interest was expressed about the deployment of Western stream-of-consciousness techniques in writing Chinese poetry. A spate of articles in leading poetry journals and newspapers like the People's Daily were engaged in a discussion of the ideological implications of such techniques. Those "early" imitations were then followed by a wave of stream-of- 
consciousness fiction in the eighties. All of these imitations, whether in poetry or fiction, were then touted as the first-ever attempts to import the Western stream of consciousness.

It was against a backdrop of enthusiasm about things Western, concomitant with a turning away from anything associated with the Soviet Union, that a flood of stream-of-consciousness imitations appeared in the so-called "Reform Era" (1979 onward). A debate ensued: the Subjectivity Debate focused on the imitations by Wang Meng, like his short stories "Sound of Spring" (1979) and "Eyes of the Night" (1979). Wang's stories raised questions about the "political correctness" of borrowing a literary form that presumably is linked not only to decadence but also to Western individualism.

From 1980 to 1983, many spoke in favor of permitting entry to the genre, which is not to be denigrated simply because it is Western. To some, although there is nothing commendable about the lifestyle portrayed in stream-of-consciousness fiction, in which hopelessness and despair is a central theme, there should not be any blanket condemnation of the genre. For others, China should seek not only technological and scientific progress, but also literary modernization as well. As an integral part of modern Western culture, such fiction cannot be dumped while other things are imported. Yet others contended that formal breakthroughs are essential to all literary revolutions, and so any genre championing formal experimentation is worth emulating. A more pervasive argument was that the borrowing of Western literary techniques had proceeded apace since the May Fourth Revolution of 1919, and this should simply be continued.

Among the debaters, however, the fact that stream-of-consciousness fiction had been imitated in China for quite some time, and only eclipsed in the three decades since 1949, when the Communists took over, was ignored. This is seen most blatantly in the way some critics proposed the possibility of Sinicizing the fictional technique. For them, the use of the literary technique can go hand in hand with the preservation of Chineseness in literary productions. A representative case can be cited here. In an article in 1988, Song Yaoliang viewed the method of stream of consciousness as a Western product borrowed by Chinese writers, who successfully used it to explore the ethical aspects of inner thought-content. ${ }^{10}$ By dissociating technique from content, he strove to make a case for a "Chinese stream of consciousness," shorn of the immoral elements associated with its Western counterpart.

One thing none of the critics of the eighties debate pointed out was that their examples of Chinese imitations were actually quite unlike their Western counterparts. While the stories of Wang Meng have delineated thought processes at length, there are no disorganized, free associations reflecting the workings of the unconscious characteristic of the works of, say, Joyce or Woolf. William Tay has pinpointed this difference by stating that "Wang Meng's narratives, though 'character-centered,' still do not fulfil our definition of stream-of-consciousness."11 Few were of course aware of this at the time, and the eighties are still, in Chinese literary history, the era most productive of Chinese stream-of-consciousness imitations. ${ }^{12}$ 


\section{0s: Taiwanese Imitations}

While Mainland Chinese critics were intent on constructing the history of the transplantation of the stream-of-consciousness genre to China in the eighties, Taiwanese critics were keen to prove that writers on the Island transplanted the genre first. In the Taiwanese accounts there is a sense of pride in being "first"; they have engaged, too, in an attempt to pass over the predecessors' contributions - seen in the failure to take note of the ones done in Hong Kong.

In a dissertation otherwise concerned with the history of the reception of Western literary theories in Taiwan, Chen Ya-chen summarizes more or less the Taiwanese version of what happened. ${ }^{13}$ According to her, after the Nationalist government established itself on the island in 1949, writers who migrated there began to look for new modes of literary expression for the "new" era. ${ }^{14}$ Ji Xuan, a prominent poet and founder of several influential literary societies at the time, advocated a "horizontal transplantation" of Western literature. As the prime example of Western modernism and the chief literary import at the time, stream-of-consciousness fiction began to be fervently imitated. Such an endeavor was supported by an entire intellectual community. Xia Ji'an, professor of foreign literature at National Taiwan University in the fifties and sixties, contributed by teaching Western modernist literature and criticism to a generation of students, some of whom used the stream-of-consciousness method in their fiction. These included Bai Xianyong, who, some claim, is the first writer to use stream of consciousness (in his short story "Hong Kong 1960") and Wang Wenxing, whose Family Catastrophe (1978) is, according to others, the first stream-of-consciousness novel in Chinese. Others, too, "preached" the imported method of writing in literary journals and newspapers during the time. Indeed, according to Chen, in their concerted work, one sees a conscious move to transplant and to relocate. This fruitful period came to an end only with the emergence of home-grown Nativist Literature in the seventies.

This history can be further examined with an eye to the selection, incorporation and rejection of historical data. While, as mentioned above, imitations of stream-ofconsciousness writing virtually disappeared on the Mainland in the sixties and seventies, this was a time when they were earnestly promoted in both Taiwan and Hong Kong. What happened in these two "peripheral" regions could be understood as a reaction to the literary situation on the Mainland. The imitations represented a counter-discourse to the socialist-realist literature avidly promoted on the Mainland, with writers in Taiwan eager to produce a kind of literature completely different from that coming out on the other side of the Taiwan Strait. ${ }^{15}$ In this light, the narrative of imitations by a Taiwanese critic like Chen cannot be complete without consideration of the ideological manoeuvrings that accompanied the transplantation of the genre of stream of consciousness to the island.

However, in this "other" history, certain historical facts languish in obscurity. Scant reference is made here to earlier imitations in thirties Shanghai and in sixties Hong Kong. When the critical essays on stream-of-consciousness fiction, as well as the handful of translations, began to whet Chinese readers' appetite for works in the new genre, the first wave of imitations already emerged in Hong Kong: Lu Yin's "Armed Christ" (1960) and William Yip's "Ulysses in Taipei" (1960). In fact, from a stylistic perspective, among the Chinese stream-of-consciousness imitations through 
the entire twentieth century, these two stories have a greater claim than any to being the first authentic imitations of the Western counterpart in question. But the part they played in effecting the transplantation of the stream-of-consciousness genre to China was never mentioned in any of the literary/translation histories coming from Mainland China or Taiwan.

\section{0s: Shanghai Neo-Sensationist Imitations}

In recent years, a third history of the introduction of stream-of-consciousness fiction to China garnered interest among literary historians, especially those based in the United States. The search for the first specimens has taken historians back to an earlier period and to a different geographical locale: writers in Shanghai in the thirties, better known as the neo-Sensationists, it is said, were the first imitators. It has been customary to regard stream of consciousness as innovative, un-Chinese, breaking bravely with conventional literary norms. Because of this, imitations of it (the theory goes) appear precisely at those times when there is a fondness for things foreign. Thirties Shanghai, therefore, provided a hotbed for imitations of stream-ofconsciousness fiction, and examples are the works of writers based there like Shi Zhecun, Mu Shiying, Liu Na'ou and Du Heng, all directly and indirectly linked with the literary journal Les Contemporaines (Xiandai), published from 1932 to 1935.

The move to credit neo-Sensationist writers, collectively, with the honor of having first imitated Western stream-of-consciousness fiction seems not only to be somewhat belated, but also contrived. The doyen of neo-Sensationist writing, Shi Zhecun, is a case in point. It is said that Shi was heavily influenced by the psychoanalytic theories of Freud and the psychological fiction of Arthur Schnitzlerin in his presentation of thought processes. He convincingly renders the private reveries and fantasies of lonely individuals; examples are the man who walks home in the rain ("One Evening in the Rainy Season," 1933), the bandit who falls in love with his sworn brother's wife ("Shi Xiu," 1932), and the moviegoer having a date with his female friend ("At the Paris Cinema," 1933).

In a close textual analysis of one passage from Shi's short story "Spring Sunshine" (1933), Leo Ou-fan Lee shows the shifts from the narrator's comments to the female protagonist's thoughts and perceptions, wielding an instance of indirect free speech, though with a brief intrusion into interior monologue (where the "I" appears). ${ }^{16}$ Indeed, of all the neo-Sensationist writers of the period, Shi was most receptive to Freudian concepts of the unconscious as the ground for understanding human psychology. The problem about calling Shi a stream-of-consciousness writer, however, is that he never sought to present characters' thoughts at the pre-verbal level, and the stylistic affinity with the acknowledged masters of stream-of-consciousness fiction is thus more apparent than real. ${ }^{17}$ The assertion that Shi had introduced stream of consciousness to Chinese readers must of necessity be qualified. The categorizing of Shi as a stream-of-consciousness imitator has yet to be elaborated.

Putting Shi aside, one still has difficulty establishing that neo-Sensationist writers were indeed the first Chinese writers to use stream of consciousness. Possible "firsts" that antedate their works are Xu Zhimo's "The Roulette" (1929) and Lin Huiyin's “In Ninety-nine Degree Heat" (1934) - both imitations of Virginia Woolf. Why has recent critical discourse singled out the neo-Sensationists, and not others 
(even Lao She, who deploys the technique in his novel Camel Xiangzi [1936-37]), as the pioneers of stream-of-consciousness fiction in China?

Perhaps the answer to these questions is not purely literary-historical. The rise of Shanghai to the status of an international metropolis is a celebrated phenomenon of the mid-nineties. Once the economic miracle had been completed, interest began to spawn with regard to the city's rich cultural past; among other things, it was here that many literary luminaries once gathered and innumerable literary groups and coteries were formed, putting out a wide array of elitist as well as popular literary magazines. The roaring thirties, it was called. By now, the study of literary Shanghai has become an academic industry. If Shanghai is to be China's representative of the "modern" city, it will be most appropriate to designate her as the place where a Chinese literary modernism originated, where the exotic stream-of-consciousness novel first landed in China.

Looking back at the history of the stream-of-consciousness imitations in China through the twentieth century, one should say that it was marked by three peaks of activity. In comparison with the two earlier peaks, a much greater effort was needed to accommodate the genre in the third "landing." Probably it was because it faced a generation of Chinese readers unfamiliar with the works of the neo-Sensationists, brought up as they were in the socialist-realist literary tradition. In all three historical accounts, each focusing on one of these peaks, there is the same sort of exclusivity and denial, exemplifying Dani Cavallaro's view that "it is in the field of historiography that reality is most blatantly distorted and yet presented as an objective chain of fact... Real occurrences are shaped, in their recording, by dominant systems of values that foreground certain elements and marginalize others." ${ }^{18}$

\section{Histories of Translations}

Writing histories of translations has become a fad in the last two decades. Comparable to the histories of imitations, they show that an ongoing project of sorts at constructing a history of translations is underway, under the influence of disciplines like comparative literature and translation studies, especially the latter. ${ }^{19}$ The burgeoning interest in the history of stream-of-consciousness translations, however, can be attributed to the enthusiasm generated by the news, since the late eighties, about two versions of a Chinese Ulysses being attempted, and then the euphoria accompanying their appearance in 1993-96.

An example of this kind of history is an article by Zha Mingjian, which surveys Joyce, Woolf, Faulkner, Proust and Hemingway translations in the course of the twentieth century. ${ }^{20}$ With one sentence at the beginning of his article, however, streamof-consciousness imitations are summarily dismissed. Zha's history is chronicled with an emphasis on the ideological factors governing the introduction of the genre to China, with special reference to the boom in stream-of-consciousness translations in the Reform Era. If, as we might agree, histories of translation always illustrate the galaxy of influences exerted by translators, readers, publishers, literary scholars, translation critics and official attitudes, then Zha has at least managed to give all of them proper representation (especially with reference to Faulkner) in his history.

Unlike the historians noted above, Zha seeks to be all-inclusive and will not leave out even apparently insignificant events. His narrative is studded with a sequence of 
historical facts and long lists of published translations. Again, unlike the three histories of imitations mentioned already, in which temporal points where the stream-ofconsciousness genre "landed" in China are identified, Zha seems to be working on the assumption that the genre did not really "land" till the completion of the monumental work of translating Ulysses in the nineties. He highlights the culminating end-point - it is almost as if the history is still incomplete without Ulysses appearing in China - rather than going back to the origins. Earlier attempts at translating other stream-of-consciousness writers, as well as partial translations of Ulysses, figure in a preparatory role in this history of transplantation via translations.

Readily observable in many accounts of how the stream-of-consciousness genre was translated in China in the last century is the theme of the gradual success attained in "taming" an untranslatable genre. Examples are the articles recently collected in a Special Issue in the James Joyce Quarterly (1997). Western linguists, making apt use of computational and statistical methods, have already told us that the genre resists transplantation. ${ }^{21}$ The Chinese critic can very well say that stream of consciousness can be more successfully deployed in Chinese, but praxis tells the translators otherwise. Hoi Fung Cheu, for instance, calls it "a task of sheer impossibility." ${ }^{22}$ In view of this, and of Zha's contention that reasons for the stream of consciousness's untranslatability are ideological, one can fairly say that the history of stream-of-consciousness translations in China is a record of how the linguistic and ideological difficulties were overcome. ${ }^{23}$

\section{Entwined Histories}

Obviously the foregoing discussion suggests a need to read the various histories of the introduction of stream-of-consciousness fiction to China - through imitations and translations - together, or as parts of a whole. The two derivative forms appear to have gone separate ways, yet from time to time either one could exert an impact on the other.

However, there is little ground for presupposing that translations encourage imitations. This point may have been argued by some translation historians eager to raise the status of translated literature, but a direct relationship has not been proved, at least in the case of stream-of-consciousness fiction as imitated/translated in China. In any case, many authors can read in the original language and do not rely on a translation to serve an intermediary role. On the other hand, neither do imitations necessarily spur translations, at least not in the case of the stream-of-consciousness novel in China. Nevertheless, if carried on extensively enough, imitations could create conditions favorable to the reception of translations. With the continued production of stream-of-consciousness imitations since the early eighties in the Mainland, a desire to read the great masterpieces through translations in Chinese might have been created. To be sure, readers had to wait for very long: it took close to half a century before the most representative works of Joyce, Faulkner, Proust and Woolf were made available in full translation.

In this connection, mention should be made of the contribution made by literary criticism. The desire to translate stream-of-consciousness fiction, which had such a canonical status in the Western world, was strong among literary scholars, and as we have seen, literary critics in Taiwan (like Tay and Yip) and on the Mainland (like 
Qu Shijiang and Li Wenjun) helped clear the way for translations through their academic publications. Through introductory articles and critical essays, an environment conducive to the translations was created. Even the Subjectivity Debate in the early eighties indirectly helped establish a rationale for translating Ulysses. Naturally, after decades of scholarly discussion of Joyce and Woolf, a desire for translations must have been created among readers of fiction in academia as well. Practically the same can be said of imitations, since those of the thirties, sixties and eighties did appear in a climate made favorable by the literary critics. The pivotal role played by relevant literary criticism is often neglected in most translation histories, but it remains a crucial factor in accounting for what happened historically.

With reference to the case in point, though one can say that the translations of stream-of-consciousness fiction followed the imitations, it is hard to prove the oftrepeated assertion that an imitator (especially a writer borrowing Western techniques) invariably learns his craft through translating. For translated poetry, much scholarly effort has been expended to show, for instance, how individual Chinese poets had been affected by the Western poets they themselves undertook to translate. This line of analysis has been pursued with reference to poet-translators both in China (Li Jinfa and Xu Zhimo) and the West (Ezra Pound). With regard to Pound, a result of such analysis is that the lines demarcating a translation from an imitation are further blurred. In the case of the stream-of-consciousness novel, as in fiction in general, it is rather difficult to prove this sort of influence, especially as translatorscum-imitators are few and far between. Shi Zhecun may be the only stream-ofconsciousness novelist who also translated novels of this genre. The majority of imitators did not translate; those who translated did not imitate.

Even where imitators were willing to admit influence, very few would presumably attribute the debt to a translation someone else did, though most authors (as imitators) might have no qualms acknowledging the debt they owe a famous foreign author. This is not surprising given the prevailing attitude that translation is after all an activity of a lower order. Many a writer have mentioned how impressed they are with translations of Joyce, Woolf and so on, but one looks around in vain yet for a writer who would claim to have been influenced by them. However, what Zha mentioned at one point in his article, referred to earlier, is important. The imitators of the eighties, with little knowledge of foreign languages and hence much less linguistically equipped than their thirties counterparts, might have relied a great deal on the translations then available to find out what the stream-of-consciousness technique was like.

On the whole, the stream-of-consciousness genre has migrated faster through imitation than translation, a fact attested by the abundance of imitations since the thirties in both Taiwan, Hong Kong and the Mainland. One can hypothesize that imitation is an easier way of tackling a foreign genre like stream of consciousness, though it is extremely difficult to generalize this observation to include other experimental fictional genres. It took longer for stream-of-consciousness fiction to be translated because, among other reasons, the linguistic resources available to deal with it "faithfully" were for quite a while wanting. It is singularly appropriate that Joyce's Ulysses, which is valorized as the pinnacle of High Modernism, got translated in the postmodern era. The entangled sentence structures, the play with words in puns and multiple allusions, as well as the criss-crossing of different registers and 
idioms, bespeak a non-mimetic and self-reflective use of language that characterizes postmodern literary expression. If the presentation of the inner workings of the mind is one obstacle to the introduction of James Joyce to China, then his deployment of a highly stylized language must be viewed as another. In the end, the greatest modernist novel was only adequately translated in the era of postmodernism. The prolonged hesitancy about translating Ulysses is evidenced by the fact that, for decades, only sections of the novel in question were translated, in contrast to a sizeable number of translations.

The relevance of imitations to a history of translation is beyond doubt; their existence makes it even harder to relegate "imported" literature to a peripheral position. Because imitations can successfully lodge a foreign literary model in native soil (much better than any domesticating attempt in translation), they are an essential link between foreign literature and indigenous literature. At the same time, there is more than one way of introducing foreign literature, the "freer" method of imitation being as useful as the more "constrained" prototypical translation. Although both are viable means of bringing about literary and cultural contact, they need not be compartmentalized: some imitations may be undertaken on the basis of translations, just as one imitation may be attempted on the basis of another (like one translation based on another). The reader is in many ways adequately prepared for them by relevant critical comments, reviews and introductions. All these intriguing relationships still await fuller investigation by the translation historian.

\section{NOTES}

1. The author wishes to thank José Lambert, Gabriel Moyal and Reine Meylaerts for their perceptive comments on earlier drafts of this article.

2. It will not be correct to talk about the Mainland case independently of what happened in Taiwan and Hong Kong. As translations and imitations were produced on the two sides of the Taiwan Strait, sometimes what was lacking on one side must be seen as being compensated for by what was produced on the other. The histories of what transpired in three regions need to be conjoined.

3. See John Dryden, "Preface to Dryden's Translation of Ovid's Epistles," in Dryden's Essays (London: J.M. Dent, 1912).

4. According to Monika Fludernik, "Linguistic Signals and Interpretative Strategies: Linguistic Models in Performance, with Special Reference to Free Indirect Discourse," Language and Literature 5.2 (1996): 93-113.

5. See Dorrit Cohn, Transparent Minds: Narrative Modes for Presenting Consciousness in Fiction (Princeton: Princeton University Press, 1978) and Taraja Rouhiainen, "Free Indirect Discourse in the Translation into Finnish: The Case of D.H. Lawrence's Women in Love," Target 12.1 (2000): 109-26.

6. Note the similar argument advanced by Naomi Matsuoka, to whom free indirect discourse is present in the Medieval masterpiece The Tale of Genji. To her, this novel has successfully rendered the intuitions, sensory perceptions and mental associations of modern stream-of-consciousness fiction. See Matsuoka, "Japanese-English Translation and the Stream of Consciousness," Tamkang Review 19.1-4 (1988-89): 537-45.

7. In the case of the Finnish translations of the stream of consciousness in D.H. Lawrence's novels, Taraja Rouhiainen (noted above) has demonstrated how they fail to capture many of the thought processes in the original text because of the absence of a deictic distinction between "he" and "she" in the Finnish language, so that the thoughts of characters are shifted onto the narrator.

8. For studies of the stylistic aspects of stream of consciousness, see (besides Cohn, cited above) Lisa Dahl, Linguistic Features of the Stream-of-Consciousness Techniques of James Joyce, Virginia Woolf and Eugene O'Neill (Turku: University of Turku, 1970); and Erwin R. Steinberg, Stream of Consciousness Technique in the Modern Novel (New York: Kennikat Press, 1979).

9. According to many, Bei Dao's Bodong is the first stream-of-consciousness novel in the post-Mao period, although it was the works of Wang Meng that turned out to be the focus of the eighties debate. 
10. See the Preface Song wrote for his own anthology, Zhongguo yishiliu xiaoshuoxuan 1980-1987 (Selected Chinese Stream-of-consciousness Fiction) (Shanghai: Shehui kexueyuan, 1998).

11. See William Tay, "Wang Meng, Stream-of-Consciousness, and the Controversy over Modernism," Modern Chinese Literature 1.1 (1984): 7-24.

12. The readers is referred to Elly Hagenaar, Stream of Consciousness and Free Indirect Discourse in Modern Chinese Literature (Leiden: CNWS, 1992) for a closer look at the eighties Subjectivity Debate.

13. See Chen Ya-chen. "Contemporary Western Literary Criticism and Theories in Chung Wai Literary Monthly, 1987-1996” (M.A. dissertation, Chung-shan University, 1998).

14. The previous generation of natives in Taiwan, educated during the period of the Japanese occupation, had written in Japanese.

15. See Christopher Lupke's enunciation of the same idea in Lupke, "(En)gendering the Nation in Pai Hsien-yung's 'Wandering in the Garden, Waking from a Dream,'” Modern Chinese Literature 6.1-2 (1992): 157-78.

16. See Leo Ou-fan Lee, Shanghai Modern: The Flowering of a New Urban Culture in China 1930-1945 (Cambridge, MA: Harvard University Press, 1999), p. 170-71.

17. This is especially so when one takes into consideration the fact that James Joyce's Ulysses was widely circulated among the members of the neo-Sensationalist group. See Shih Shu-mei, The Lure of the Modern: Writing Modernism in Semicolonial China, 1917-1937 (Berkeley: University of California Press, 2001), p. 239.

18. Dani Cavallaro, Critical and Cultural Theory: Thematic Variations (London: The Athlone Press 2001), p. 34.

19. The historicizing impulse in translation studies has reared its head in the mid-nineties, represented by the Göttingen school in Germany and a spate of theoretical works published in Europe (written by Anthony Pym, among others). In China, the impact came slowly, but it did eventually.

20. See Zha Mingjian, "Yisiliu xiaoshuo zai xinshiqi de yijie jiqi 'yingxiang yuan wenben' yiyi” (Translations of the Stream-of-consciousness Novel in the New Era and the Meaning of the 'Influencing Source Text'), Zhongguo bijiao wenxue no. 4 (1999): 59-72.

21. Lisa Lena Opas and Pekka Kujamaki have written at length on the difficulties of translating the genre from a linguistic perspective, with reference to Finnish, German and Swedish translations of Samuel Beckett's How It Is and All Strange Away. See Opas and Kujamaki, "A Cross-Linguistic Study of Stream-of-Consciousness Techniques," Literary and Linguistic Computing 10.4 (1995): 287-91.

22. See Hoi, “Translation, Transubstantiation, Joyce: Two Chinese Versions of Ulysses," James Joyce Quarterly 35.1 (1997): 59-70.

23. Recently, efforts were made to do translations of complete works by stream-of-consciousness. The desire to have the "complete" Joyce or Woolf is symptomatic of the optimism about overcoming linguistic obstacles and cultural barriers. A phenomenal event, in this context, is the completion of the multi-volume Remembrance of Things Past by Marcel Proust. 